\title{
CONGLOMERATE TUBERCULOSIS OF THE IRIS WITH SCLERAL PERFORATION*†
}

\author{
BY
}

\author{
COLIN WALKER \\ Southampton Eye Hospital
}

THIS disease is rarely met with and it is interesting, therefore, to observe the effect of modern therapy on a condition which by all accounts almost invariably led to perforation of the globe and loss of the eye (Duke-Elder, 1940).

\section{Case Report}

A 73-year-old married woman attended the Southampton Eye Hospital in July, 1962, with a history of an inflamed eye and blurred vision for 2 weeks. There had been no previous eye disease, there was no pain, and the patient's general health was good apart from swelling of the legs at times.

Examination.-A granulomatous iritis was found with slight corneal haze, a flare, and large "mutton-fat" keratic precipitates. The visual acuity was $6 / 18$, not improved with glasses.

Treatment.-She was given subconjunctival injections of mydricaine and cortisone and local mydriatic and steroid drops.

Progress.-A week later the inflammatory signs were less but a nodular swelling of the iris developed at 5 o'clock, narrowing the anterior chamber at this point.

Diagnosis.-A provisional diagnosis of ocular sarcoid was made and further investigations yielded the following results:

CHEST FILM: "No evidence of sarcoidosis. Heart enlarged to the left and hypertensive in shape. Both lungs clear".

haEmATOlOGY: $\mathrm{Hb} 14 \mathrm{~g} . / 100 \mathrm{ml}$. Erythrocyte sedimentation rate $18 \mathrm{~mm}$. in $1 \mathrm{hr}$; leucocytes $5,000 / \mathrm{cm}$; ; neutrophils 73 per cent.; lymphocytes 20 per cent.; monocytes 7 per cent. Red blood cells and platelets normal. Wassermann and Price's precipitation reactions negative. Total serum protein $6.6 \mathrm{~g} . / 100 \mathrm{ml}$.; albumin $4 \cdot 1$; globulin $2 \cdot 5 ; \mathrm{A} / \mathrm{G}$ ratio $1.64: 1$. Agglutinations for typhoid, paratyphoid, and brucella negative. Mantoux test weak positive to $1 / 100$.

URINE: normal.

BLOOD PRESSURE: $210 / 110$.

PHYSICIAN'S REPORT.- - "Hypertension with gravitational leg oedema and an enlarged spleen. No evidence to suggest sarcoidosis or other granulomatous diseases".

Further Developments.-In view of these rather unhelpful results, local medication was continued, with slight general improvement of the eye, until December, when, after a series of cancelled appointments due to the bad weather the eye appeared as shown in Fig. 1 (opposite). A large intensely inflamed protuberant nodule, not unlike a florid episcleritis, projected from the globe behind the limbus at 5 o'clock. The iris nodule had shrunk and seemed to have given rise to it. Minute sinuses were visible at the apex of the lesion and small satellite nodules were present around it. The conjunctiva appeared intact over the mass.

* Received for publication November 9, 1965 .

$\dagger$ Address for reprints: Eye Hospital, Wilton Avenue, Southampton, Hants. 


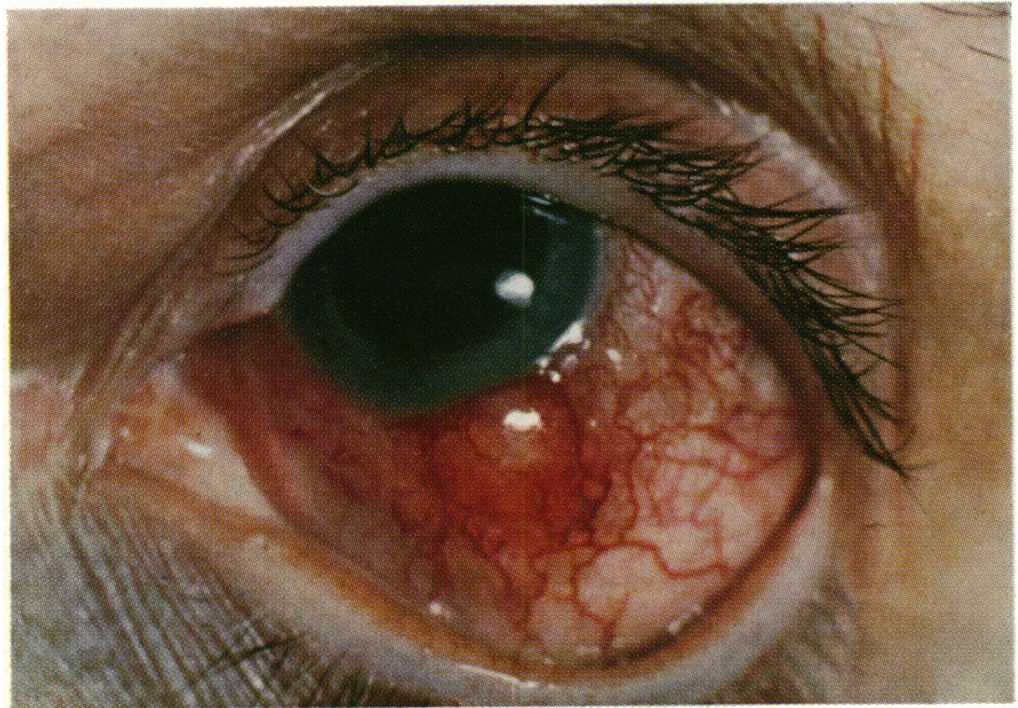

(1)

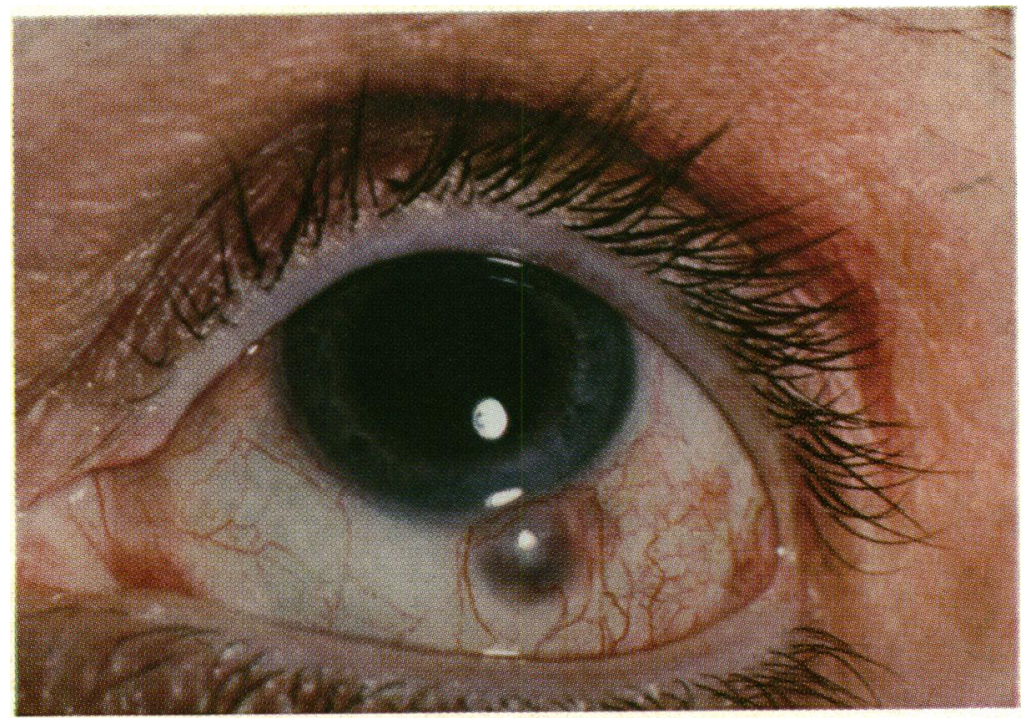

(2)

Fig. 1.-Condition on admission in December, 1962, showing inflamed nodule at limbus threatening perforation.

FIG. 2.-Condition 3 months later after successful treatment with anti-tuberculous drugs. These appearances have remained unchanged to the present time. 
Treatment.-The patient was admitted to hospital and treated as a case of conglomerate tubercle of the iris threatening to perforate with $1 \mathrm{~g}$. streptomycin daily; 2 cachets PAS and isoniazid four times a day, and prednisolone $5 \mathrm{mg}$. four times a day.

10 days later signs of flattening of the lesion and disappearance of the satellites were observed, and 3 weeks after admission she was discharged on streptomycin $3 \mathrm{~g}$. weekly in divided doses, prednisolone $5 \mathrm{mg}$. three times a day, potassium chloride $1 \mathrm{~g}$. daily, and PAS as before.

The streptomycin was stopped after 6 weeks and the prednisolone reduced to twice daily.

In March, 1963, the lesion appeared as in Fig. 2; it was almost completely flat and whorls of fibrous tissue covered it. A reduction of the dosage of PAS to 2 catchets twice daily, however, was followed by a relapse of the uveitis, but this subsided with a return to the previous dosage.

Result.-All treatment was finally stopped in January, 1965, the final visual acuity being 6/9.

\section{Comment}

It is interesting that the first description of a case of uveal tuberculosis (Maitre-Jan, 1707) was apparently one of an iris lesion perforating the cornea. Saunders (1811) described a case suggestive of tuberculous perforation, but it is clear from his paper that at that date a distinction could be attempted only between malignant and non-malignant perforations of the globe, unless obvious systemic disease was present. Lawrence (1833) described "non-malignant extrusions from the eye" and Jaeger (1831) described perforation from a lesion in the ciliary body. Lagrange (1924) rationalized the subject on the basis of the classic experiment of intracarotid injection of Cohnheim (1867), but using known tubercle bacilli in his animals. Lagrange (1933) also described irido-ciliary tuberculomata in young adults, and remarked on the frequent resemblance to tumour, the blockage of the filtration angle, and the absence of systemic disease; more especially he pointed out the strong tendency to perforation. Finnoff (1931) reiterated the absence of other clinical manifestations but added that death from systemic tuberculosis not uncommonly ensued. Choyce (1952) noted the frequent unreliability of the skin sensitivity tests for diagnosis; Woods (1961) discussed these at length and related the possible results of these tests to various ocular manifestations of the disease.

The value of specific therapy as a diagnostic test is generally agreed and this is perhaps the only significant advance in diagnosis since the time of the early clinicians.

I should like to thank Prof. Norman Ashton for his helpful advice and Mr. White, photographer to the Southampton Hospital Group, for the colour prints.

\section{REFERENCES}

CHоYCE, D. P. (1952). Trans. ophthal. Soc. U.K., 72, 279.

Cohnheim, J. (1867). Virchows Arch. path. Anat., 39, 49.

DuKe-Elder, S. (1940). " "Text-book of Ophthalmology", vol. 3, p. 2285. Kimpton, London.

Finnoff, W. C. (1931). Amer. J. Ophthal., 14, 127.

JAEGER, E. (1831). "Ueber Markschwamm des Auges und amaurotisches Katzenauge”, p. 78. Würzburg.

LAGRANGe, H. (1924). "La tuberculose du tractus uvéal", p. 28. Doin, Paris. (1933). "La tuberculose de l'iris et du corps ciliaire", p. 322. Doin, Paris.

LAWRENCE, W. (1833). "A Treatise on the Diseases of the Eye", p. 591. Churchill, London.

Maître-JAN, A. (1707). "Traité des maladies de l'oeil", p. 411. Febvre, Troyes.

SAunders, J. C. (1811). "A Treatise on Some Practical Points relating to the Diseases of the Eye", p. 117. Longman, London.

Woods, A. C. (1961). "Endogenous Inflammations of the Uveal Tract", p. 61. Williams and Wilkins, Baltimore. 